\title{
Motivational Aspects of Information Literacy Skills Instruction in Community College Libraries
}

\section{Ruth V. Small, Nasriah Zakaria, and Houria El-Figuigui}

\begin{abstract}
This study explored the motivational aspects of information literacy skills instruction delivered by librarians in community college libraries. Librarians and students at seven community colleges were interviewed and observed. Involvement of faculty, use of technology, and students' on- and off-task behaviors also were investigated. Data analyses used Keller's ARCS Model, ACRL standards, and Small and Arnone's Motivation Overlay for Information Skills Instruction. The majority of strategies used were to gain and maintain students' attention. The range of strategies, rather than the number of strategies, appeared to positively affect student motivation.
\end{abstract}

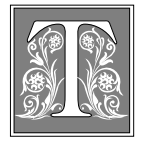

he ALA defines information literacy as the ability "to recognize when information is needed and have the ability to locate, evaluate, and use effectively the needed information." ${ }^{11}$ Information literacy (IL) has been a "hot topic" in academic library literature for the past ten years with the teaching of IL skills an increasingly important component in twenty-first-century higher education, central to the mission of lifelong learning. ${ }^{2,3}$ Abby Kasowitz-Scheer and Michael Pasqualoni have stated that the teaching of IL skills "requires a shift in focus from teaching specific information resources to a set of critical thinking skills involving the use of information." ${ }^{\prime 4}$ They cited three methods currently used to deliver IL skills: online, in a separate course, and integrated across the curriculum. The latter is preferred because it ties information literacy to students' other learning, thereby making it a just-in-time teaching strategy as opposed to a just-in-case one.

The teaching of information literacy may be particularly critical for students at the community college level. ${ }^{5}$ The teaching of IL skills, including research and critical thinking skills, has been described as a primary role of library faculty in community colleges. ${ }^{6}$

With emphasis on IL skills instruction gaining importance in and centrality to instructional programs in higher education, the need for research on best practice becomes essential. Instructional methods used to effectively present information and motivate student learning are the focus of this study.

Ruth V. Small is a Professor in the School of Information Studies at Syracuse University; e-mail: drruth@syr.edu. Nasriah Zakaria and Houria El-Figuigui are doctoral students in the School of Information Studies at Syracuse University; e-mail: nazakari@mailbox.syr.edu and helfigui@syr.edu. The authors wish to acknowledge the commitment and dedication of the community college librarians who participated in this research study and the graduate students and practitioners who contributed to its success. This research study was funded by the 2001 Carroll Preston Baber Research Award from the ALA. 


\section{Statement of the Problem}

Charles Hayes has stated that first-year college students frequently lack the library research skills required to do a college-level research paper. ${ }^{7}$ The role of teacher has become a fundamental responsibility for librarians. ${ }^{8}$ According to Carla J. Stoffle, the challenge to academic librarians is to "learn how to be effective teachers and designers of assignments in more systematic ways than the hit-ormiss methods in vogue today." ${ }^{\prime 9}$ Michele Mednick has described academic librarians as key members of instructional teams and instructional partners with faculty. ${ }^{10}$ This involves more than just teaching IL skills so that students can complete assignments or solve information problems. Information literacy is more than a framework of knowledge and a set of skills, it is an attitude that reflects an interest in seeking solutions to information problems, recognition of the importance of acquiring information skills, information confidence rather than information anxiety, and a sense of satisfaction that comes from research competence.

Ideally, therefore, effective IL skills instruction not only helps students acquire the skills they need but also stimulates intellectual curiosity, encourages information-seeking and exploration behaviors, and sparks a passion for lifelong learning. ${ }^{11}$ It requires active learning by students. ${ }^{12}$ However, one of the major challenges facing the IL instructor is to provide the type of active learning strategies and experiences that motivate students to learn and apply these skills. ${ }^{13}$ This study explores the ways in which community college librarians motivate students during instruction.

\section{Information Literacy Skills}

The ALA describes the need for students to acquire IL skills (i.e., knowledge of techniques for accessing and evaluating information) as essential skills for lifelong learning. ${ }^{14}$ Although it is generally acknowledged that community college students need to be information literate, many continue to lack the skills required to be successful in their courses..$^{15}$ In a report on the roles and responsibilities of library faculty by the Academic Senate for California Community Colleges, it was stated that "(1)ibrary faculty instruct in information literacy skills, which include the ability to access, retrieve, analyze, evaluate and apply information. These skills are essential to current and lifelong learning processes. ${ }^{16}$ Further, this document cites the collaborative role of the community college librarian in curriculum development and support "as partners in the classroom, as specialists and facilitators in the use of information the retrieval for print, media, electronic and digital information environments." 17

In 2000, the Association of College and Research Libraries (ACRL) published its Information Literacy Competency Standards for Higher Education, which identified five general IL standards with a number of performance indicators for each standard. These standards are:

1. The information-literate student determines the nature and extent of the information needed.

2. The information-literate student accesses needed information effectively and efficiently.

3. The information-literate student evaluates information and its sources critically and incorporates selected information into his or her knowledge base and value system.

4. The information-literate student, individually or as a member of a group, uses information effectively to accomplish a specific purpose.

5. The information-literate student understands many of the economic, legal, and social issues surrounding the use of information and accesses and uses information ethically and legally. ${ }^{18}$

Students must learn to locate, evaluate, and use information in all forms and, typically in education contexts, these skills are taught and/or reinforced by librarians. Burdick emphasizes the importance of information skills instruction that develops both ability (i.e., knowledge and skills) and desire (i.e., motivation). ${ }^{19}$ 


\section{The Importance of Motivation}

Maureen Kilcullen has stated that "Knowing what motivates students and how they learn is essential to teaching critical thinking skills in library users... . Thinking about motivation and learning theories while planning library instruction may well help instruction librarians become better teachers. ${ }^{20}$ Student-centered teaching methods such as problem-based learning and inquiry learning are most effective for teaching IL skills in a way that is integrated with curriculum content, structure, and sequence. ${ }^{21}$

In a study exploring the use of motivational strategies in instruction in higher education, Ruth V. Small, B. M. Dodge, and $X$. Jiang found that attention-gaining strategies such as variety, surprise, and novelty were most effective in generating interest and preventing learning boredom..$^{22}$ They also found that instructional technologies that do not capture students' attention and are not directly relevant to the content and goals of the instruction may actually promote learning boredom.

Small, Dodge, and Jiang also looked at the role of instructors in stimulating student motivation. They found that learners perceived their instructors as having the primary responsibility for motivating them. This means that instructors are expected to design strategies into their instruction that enhance learner interest and reduce learner boredom. This study looks at the librarian's role as teacher in the community college environment and the strategies that librarians use to motivate their students during IL skills instruction.

To date, research on and development of IL skills instruction have focused almost exclusively on content (the research process) or learning outcomes, with little or no attention paid to presentation methods that influence student motivation. Although some research has been done on the effectiveness of specific motivational teaching methods and strategies in $\mathrm{K}-12$ classrooms and school library media centers, little research has been done to date that examines the use of motivators within the unique context of IL skills instruction in higher education. ${ }^{23}$ In fact, little is known about the type and number of motivators that appear to be most effective in stimulating students' task engagement in and enjoyment of the research process.

Carol C. Kuhlthau is one of the few researchers to recognize the importance of motivation in information science research. ${ }^{24}$ However, her research focused on (1) the feelings and attitudes of students as they proceed through the research process and (2) more general elements of successful IL programs, rather than on specific instructional interventions to improve student motivation. For example, she described the "exploration stage" of research as the most difficult for students because they encounter information that is "inconsistent and incompatible and does not match what they already know." ${ }^{25}$ Yet, some educational researchers suggest that some uncertainty and incongruity are useful for stimulating curiosity and interest. ${ }^{26}$ Therefore, a modest amount of uncertainty may motivate students during the research process, whereas too much uncertainty will likely cause anxiety and frustration.

In a study that investigated which factors college students considered to be most effective in avoiding and causing boredom, Small, Dodge, and Jiang found that students perceived their instructors to be the primary source of their learning interest and boredom. ${ }^{27}$ The factors students considered most likely to cause learning boredom were a dry, monotone delivery style; repetition of information students already knew; the presentation of irrelevant information; and a lack of variety of teaching methods. The researchers also found that the most effective factors students cited for preventing learning boredom were opportunities for student participation and interaction; relevant content; the use of humor; instructor enthusiasm; and a variety of teaching methods.

Small studied the motivational strategies used by elementary and middle school library media specialists (LMSs) during IL skills instruction using John M. Keller's ARCS Model of Motivational Design as the basis for analysis. ${ }^{28,29}$ The 
ARCS Model consists of four requisite components to motivating instruction: (1) gaining and sustaining $[\mathrm{A}]$ ttention to the instruction by stimulating curiosity and interest, (2) providing the [R]elevance (importance, value) of the learning, (3) building learners' [C]onfidence in their abilities to succeed at the learning task, and (4) promoting the potential for learning [S]atisfaction. Keller broke each of the ARCS components into three subcomponents, each of which suggests a wide range of motivational strategies to incorporate into instruction (some examples are given).

\section{- Attention}

o Perceptual Arousal (A-PA) (e.g., an incongruous or unexpected event, humor, novelty)

o Inquiry Arousal (A-IA) (e.g., questioning, problem-solving activities)

o Variability (A-V) (e.g., change of pace, format, or media)

- Relevance

o Goal Orientation (R-GO) (e.g., specification of learning objectives, present value, and future use of learning)

o Motive Matching (R-MM) (e.g., content and examples that relate to learners' previous learning and experiences, positive role models, learning choices)

o Familiarity (R-F) (e.g., concrete and familiar language and examples)

- Confidence

o Learning Requirements (C-LR) (e.g., clearly specified criteria for successful learning or performance)

o Success Opportunities (C-SO) (e.g., an attainable challenge, practice opportunities)

o Personal Control (C-PC) (e.g., shared control of the pace or amount of content presented)

\section{- Satisfaction}

o Natural Consequences (S-NC) (e.g., opportunities to immediately use newly acquired knowledge or skill in a real or simulated setting)

o Positive Consequences (S-PC) (e.g., provide positive feedback and reinforcements that will sustain the desired behavior, unexpected rewards) o Equity (S-E) (e.g., maintain consistent standards and consequences for learning accomplishments).

Other researchers have used the ARCS Model as a framework for categorizing motivational strategies used in instruction, but only Small has applied it to IL skills instructional contexts, specifically the $\mathrm{K}-8 \mathrm{li}-$ brary setting. ${ }^{30,31}$ Her study found that although these librarians used a large number of motivational strategies (averaging 24 strategies per lesson), the strategies were overwhelmingly designed to capture and maintain attention and interest (more than half of all strategies were questioning or problem-posing strategies used at the beginning or during the lesson) and only a few were intended to demonstrate the value of learning information skills, inspire students' confidence in their research ability, and ensure satisfaction with the students' research results and skills learned, equally important motivational outcomes.

\section{Intrinsic versus Extrinsic Motivation}

The literature identifies two general categories of motivational orientations: intrinsic and extrinsic. ${ }^{32}$ Students with an intrinsic (or internal) orientation find satisfaction from simply participating in a learning experience that stimulates their curiosity and interest, promotes their feelings of competence or control, and/or is inherently pleasurable. ${ }^{33}$ Instructors who encourage an intrinsic orientation create challenging learning situations that allow students to have some control over their learning and promote feelings of competence and mastery.

Students with an extrinsic (or external) orientation are motivated to learn or perform by such things as rewards and incentives. Instructors who encourage an extrinsic orientation create a learning environment where students pursue a learning task because it provides satisfaction in the form of some type of external motivator or reward (e.g., a prize, verbal praise, a high grade) that is independent of the activity itself and controlled by someone other than the student (e.g., a teacher, a computer system). 
FIGURE 1

The Motivation Overlay for Information Skills Instruction

\begin{tabular}{|c|c|c|c|}
\hline Research Stages & Beginning & During & Ending \\
\hline $\begin{array}{l}\text { Information } \\
\text { skills }\end{array}$ & $\begin{array}{l}\text { Definition } \\
\text { Selection } \\
\text { Planning }\end{array}$ & $\begin{array}{l}\text { Exploration } \\
\text { Collection } \\
\text { Organization }\end{array}$ & $\begin{array}{l}\text { Presentation } \\
\text { Evaluation }\end{array}$ \\
\hline \multirow[t]{3}{*}{$\begin{array}{l}\text { Motivational } \\
\text { goals }\end{array}$} & $\begin{array}{l}\text { Generate interest in } \\
\text { the research process }\end{array}$ & $\begin{array}{l}\text { Maintain interest in } \\
\text { the research process }\end{array}$ & $\begin{array}{l}\text { Encourage ongoing } \\
\text { confidence in } \\
\text { research ability }\end{array}$ \\
\hline & $\begin{array}{l}\text { Establish importance } \\
\text { of information skills }\end{array}$ & $\begin{array}{l}\text { Promote value of } \\
\text { information skills }\end{array}$ & $\begin{array}{l}\text { Promote satisfaction } \\
\text { in research accom- } \\
\text { plishments }\end{array}$ \\
\hline & $\begin{array}{l}\text { Build confidence in } \\
\text { research ability }\end{array}$ & $\begin{array}{l}\text { Reinforce confidence } \\
\text { in research ability }\end{array}$ & $\begin{array}{l}\text { Motivate continuing } \\
\text { information exploration }\end{array}$ \\
\hline $\begin{array}{l}\text { Related } \\
\text { motivational } \\
\text { theories }\end{array}$ & $\begin{array}{l}\text { Expectancy/value } \\
\text { Need } \\
\text { Curiosity } \\
\text { Attribution } \\
\text { Social learning }\end{array}$ & $\begin{array}{l}\text { Expectancy/value } \\
\text { Need } \\
\text { Flow } \\
\text { Attribution } \\
\text { Social learning }\end{array}$ & $\begin{array}{l}\text { Expectancy/value } \\
\text { Attribution } \\
\text { Curiosity } \\
\text { Social learning }\end{array}$ \\
\hline
\end{tabular}

Cognitive evaluation theory identifies two types of rewards: those intended to control and those intended to provide meaningful information. ${ }^{34}$ The more controlling the reward (e.g., "Finish this exercise and you can leave"), the more it decreases existing intrinsic motivation. The more informational the reward (e.g., "Because you have worked hard and mastered these research skills, you can use the rest of the period to explore additional resources on the $\left.W^{\prime \prime} b^{\prime \prime}\right)$, and the closer it is tied to the task itself, the more the reward increases feelings of competence and selfdetermination and enhances existing intrinsic motivation.

Marshall found that when teachers used intrinsic motivators (i.e., tied learning success to the student's efforts and abilities), there was a higher rate of on-task behavior and higher motivation toward the task..$^{35}$ Teachers who encourage an extrinsic orientation tend to (1) be more controlling and authoritative, (2) present feedback in a controlling (rather than informational) manner, and (3) avoid providing students with choices in how they learn and study. ${ }^{36}$ Extrinsic rewards, particularly those unrelated to the learning task, can have a detrimental effect on intrinsic motivation. ${ }^{37}$

Building on the work of Small, Keller, and Kuhlthau, Small and Arnone developed the Motivation Overlay for Information Skills Instruction. ${ }^{38,39}$ (See figure 1.) The Motivation Overlay synthesizes existing IL models into eight basic IL skills (which roughly correspond to the first four ACRL standards) over three general time periods. Nine motivational goals are associated with each time period and related skills.

Subsequently, Small and Arnone identified a variety of motivational techniques that they suggested formed an educator's "motivation toolkit," that is, a set of motivational interventions for K-12 IL instruction that addresses specific motivational goals and research skills at each of the three stages of the research process. Research is needed to identify such interventions for IL instruction at the college level that help to reduce the level of anxiety students often experience and to motivate positive feelings and attitudes during the research process.

This study represents an initial attempt to document the types of motivational strat- 
egies used by community college librarians during instruction and to examine their impact on students. The Motivation Overlay was used as a framework for identifying on which research stages and information skills the instruction is focused.

\section{The Role of Collaboration}

Successful collaboration is based on common goals, a shared vision, and a climate of trust and mutual respect. ${ }^{40}$ To be motivated to collaborate, all participants must see personal value in collaborating and believe they have the capability to be successful collaborative partners.

Collaboration between librarians and professors is essential to the success of IL skills instruction. Students will respond to instruction in which their professor's voice and objectives are visible, that is, where the instruction is connected to the curriculum and tied to course activities and/or assignments. ${ }^{41}$ Christine Susan Bruce extended that connection to life experiences and professional contexts. ${ }^{42}$ This requires active collaborative planning and delivery of instruction by both partners. This study documented the level of involvement of faculty in IL skills instructional delivery in community college libraries.

\section{The Importance of Technology}

In 1998, Stoffle stated that for effective learning to take place in higher education, librarians must learn to integrate new technologies into the IL instructional program, using technology effectively to deliver instruction to students. ${ }^{43}$ Technology also has become a vital tool for accessing a wide variety of electronic resources; thus, technology fluency goes beyond just learning how to use a computer to sophisticated searching and evaluation skills.

Although technology cannot be considered the total solution to low student learning motivation, P. Sallman asserted that "carefully used in a well-developed unit designed around the needs of students, (technology) can provide just what the doctor ordered to help motivate students and enhance learning for everyone involved." ${ }^{44}$ Technology may be used to deliver the instruction (e.g., PowerPoint presentation) and/or used as the content focus of the lesson (e.g., searching databases). This research study builds on Small's work and the work of Small and Arnone by exploring how and what technology is used by community college librarians and if and how that technology affects student motivation.

\section{Research Questions}

This study explored the use of motivational strategies in IL skills instruction by community college librarians (CCLs). Research questions explored were:

1. What background knowledge and experience influence information literacy skills instruction by CCLs?

2. At the community college level, which of the ACRL Information Literacy Standards and Motivation Overlay's research stages and IL skills receive the most/least emphasis during information literacy skills instruction?

3. What motivational techniques are used by community college librarians (CCLs) in their information literacy skills instruction, and how do those techniques differ from those used by school librarians?

4. What task engagement and information-seeking behaviors are exhibited by community college students as a result of specific motivational techniques used during information literacy skills instruction?

5. How do students perceive the motivational quality of their information literacy skills instruction?

6. What is the level and extent of community college faculty participation in information literacy skills instruction, and how does participation/nonparticipation affect student motivation?

7. In what ways do community college librarians use technology in information literacy instruction, and does the use of technology subsequently affect student motivation?

\section{Setting}

"The Community College library that offers a well structured but flexible library instructional program provides an aca- 
demic learning tool that enhances and significantly contributes to student success. ${ }^{145}$ Community college libraries were chosen for study because:

- Their primary mission focuses on the teaching and learning of IL skills. ${ }^{46}$ For example, D. M. Smith has reported that her community college library delivers approximately two hundred IL workshops a year, reaching more than 50 percent of the student body. ${ }^{47}$

- Their student body is typically more varied and diverse in terms of needs and learning styles (e.g., more part-time students, more nondegree seekers, larger representation of racial and ethnic minorities and students with disabilities). ${ }^{48}$

- There is generally greater teacherlibrarian collaboration, participation in instructional planning and delivery, and acceptance of librarians as teaching equals than at other academic institutions. ${ }^{49}$

- There has been greater acceptance by community college librarians of the integral role of information technologies in FIL skills instruction than at other higher education institutions. ${ }^{50}$

\section{Methods}

Investigating the use of motivational techniques and strategies used by community college librarians requires repeated observations over extended periods of time. This study involved observations of ten teaching episodes of ten librarians at seven community college libraries over a one-year period. The seven community colleges were located in Pennsylvania (1), New York (3), Connecticut (1), California (1), and Utah (1).

A team of seven student observers from a graduate program in library and information science was recruited and trained to conduct observations and pre- and postobservation interviews and to record and report observation and interview data. The lead researcher reviewed each observation for quality and completeness and to ensure consistency across observations.

To obtain the geographically widest possible range of sites, the researcher recruited graduate students from both the campusbased and distance graduate student body of the researcher's academic unit to serve as observers. This required the development and implementation of Web-based training for all observers. Using WebCT, a flexible, integrated online tool used mostly in distance learning, each observer participated in the data collection training, which included (1) general procedures; (2) specific directions for conducting preobservation interviews, observations, student interviews, and postobservation interviews; (3) examples of two completed observations to serve as models; and (4) all data collection forms. (See the appendix.)

Observers conducted pre- and postobservation interviews with each librarian. The preobservation interview protocol was developed to gather demographic data, including information about the college, the students, the library, and the professional preparation and experience of each participating librarian (e.g., Describe the type and range of students who attend your college) and some preliminary information about the instructional program (e.g., What topic or topics do you teach most frequently?). Following completion of each observation, the observer conducted a postobservation interview with each participating librarian that focused on teaching philosophy, attitudes toward technology, preferred teaching methods, and collaborative instructional planning with faculty (e.g., What is your general teaching philosophy? What are some of your favorite/most frequently used teaching techniques?). A brief interview protocol was developed to explore feelings and perceptions of one randomly selected student from each observed lesson. The questions asked students to categorize the lesson in terms of interest and confidence building and to describe its benefits. For example, one question asked, What was the most important thing you learned in the instruction you just received?

Each observer was assigned to a single community college library in order to track performance of the same instructor(s) over time. Librarians were selected for participation in this study on the basis of the following criteria: They had (1) an estab- 
lished, instructional program in which library and information skills are regularly taught to community college students and (2) at least one year of experience teaching IL skills in a community college library.

Before any data were collected, it was discovered that many community college libraries utilized two or more librarians as instructors. This differed from the K-8 library setting in which, typically, only one LMS serves the entire school and teaches IL skills to all students. To ensure that there are enough observations at each site and to avoid data collection that was too distributed resulting in very few observations per librarian instructor, it was decided to limit the number of librarians observed at any one site to two; therefore, observers at three sites had to extend their observations and interviews to two librarians.

Moreover, it was discovered that, unlike $\mathrm{K}-8$ schools where IL skills lessons were conducted regularly each week, most of the instruction in community college libraries was done at specific times of the year (e.g., at the beginning of the year as an orientation). Because of this and some scheduling issues, the schedule of observations for some observers had to be extended over an entire academic year.

Two coders (information specialist practitioners) served as independent raters for coding observation data. They were the same coders who coded observation data for the 1999 Small study; therefore, they were experienced in coding these particular types of data. Two doctoral students in information transfer served as research assistants. One performed content analyses on all interview data, and the other focused on observation data only, analyzing the use of technology, participation of faculty, and onand off-task behaviors of students.

\section{Procedures}

After conducting a preobservation interview with the instructional librarian, each observer was directed to observe ten randomly selected UL skills lessons in their entirety, looking at a variety of topics and classes of students. Due to scheduling problems, the time frame for collecting data was extended to a full academic year.

In addition to identifying the subject and length of each lesson, the size and makeup of the class, and the learning environment (e.g., library, classroom, computer cluster), observers' note-taking focused on the following: the librarian; general instructions; the number and type of verbal and written interactions; questioning and feedback strategies; presentation methods; use of technology, media, and materials; and nonverbal communication. At approximately ten-minute intervals during the session, the observer was asked to shift focus, recording number, type, and level of student on-task (e.g., interacting directly with the assigned activity, responding to a question) and offtask (e.g., talking to each other on topics unrelated to the instruction, reading unrelated materials) behaviors. When each observed lesson had been completed, each observer randomly selected one student from each lesson to interview.

After all the data were collected, typed, and submitted to the lead researcher, all narratives were reviewed and all motivational strategies were identified and coded by two trained independent raters. The content of the sixty-nine student interviews was coded and analyzed. Data were analyzed using content analysis and descriptive statistical methods.

\section{Results}

Data were collected through observations and interviews with librarians and students. Ten librarians at seven community colleges were observed by seven trained observers (two librarian participants were observed at three of the sites). A total of seventy observations and student interviews were completed; however, data from one observation and student interview were lost through computer malfunction, making a total of sixty-nine observations and student interviews available for analysis.

The lead researcher reviewed all of the observation data and extracted all teaching strategies that were then given to the two coders. The two coders assessed the 
overall lesson according to ACRL information literacy standards, motivation stages, and information skill(s) taught, and coded each strategy by ARCS components and subcomponents. Each coder initially rated the data independently, and then the two coders compared ratings. Where differences occurred, the coders discussed and attempted to resolve them. All differences were resolved, making interrater reliability 1.00. The research assistants analyzed the coding results using descriptive statistics and performed content analyses on the librarian and student interviews.

\section{Background Information}

Two of the community colleges in the study were located in urban areas, three in suburban areas, and two in rural areas. Student populations ranged from small $(2,232)$ to large $(25,000)$, with an average of 9,683 students per college. Students ranged in age from a recent high school graduate to older adults. Classes observed included first- and second-year students from a wide variety of academic disciplines, including English, writing, nursing, psychology, modern languages, art, education, reading (remedial English), anthropology, sociology, political science, and freshman study skills. Some students were enrolled in a certificate program, some were pursuing an associate degree, and others were just taking courses to acquire new knowledge or skills as nonmatriculated students.

The years of professional service as librarians ranged from one year to twelve, with an average of five years. This is in contrast to the Small study in which the years of service for K-8 LMSs ranged from three to thirty-three, with an average of eleven years. This is consistent with the large number of school LMSs nearing retirement.

The libraries at the different community college research sites offered three to twenty classes on information literacy every week, with an average of five classes. Among these, the number of classes taught by the librarian participants ranged from one to ten per week, with an average of two classes. At some of the community colleges, there were specific times during the year where several class visits were scheduled in a short time period and other times where few or no class sessions were scheduled. Therefore, some observers completed their observations within a few months; others took almost a year to complete them.

Most of the libraries described their instructional programs as falling into three main categories:

- bibliographic instruction, where presentations range from the use of library resources to research strategies appropriate to a particular subject area;

- tailored instruction (classes requested by faculty or individual consultation);

- introduction to research (e.g., gather background information about a topic).

Some of the community colleges also offer computing literacy classes where students learn Internet basics. When asked about the most frequently taught topics by themselves, almost all librarians mentioned searching the library catalogs, databases, electronic journals, and the Internet. They cited the focus of these sessions as ways to access these information systems, the research process, search strategies, and evaluation criteria for information retrieved.

Lessons averaged sixty-four minutes in length, ranging from twenty-five minutes to two hours. The average number of students per lesson was sixteen, with students per lesson ranging from four to thirty-five.

Research question \#1. What background knowledge and experience influence information literacy skills instruction by CCLs?

In pre- and postobservation interviews, librarians were asked a number of questions about their personal teaching philosophy, methods, and backgrounds. When asked how and from whom they learned to teach, half the librarians (5) stated that they held teaching degrees. This is contrary to Kilcullen's statement that "(f)ew librarians learn to teach by formal coursework" 51 The other five stated that they learned to teach by watch- 
ing others (e.g., supervisor, faculty, colleagues), reading material on teaching, or just doing it over time, which is consistent with the literature. ${ }^{52}$

When asked to share their teaching philosophy, librarians mentioned establishing a friendly, comfortable environment as the most important method for facilitating learning in the classroom. Sharing knowledge through a collaborative learning environment and hands-on teaching also were prominently mentioned. Well preparedness and enthusiasm of the instructor were cited as highly important for stimulating interaction and improving student performance. When asked about their most frequently used teaching techniques, nine of ten liked to demonstrate (e.g., teaching by example) and then immediately get students to practice the task. Other teaching techniques cited were use of humor, interactivity, use of current events, and positive reinforcement techniques (e.g., candy). Most of these descriptors are consistent with what students cited as strategies used by instructors that motivate learning. ${ }^{53}$ Librarians believed that these techniques (1) help students retain knowledge and skills, (2) make the library a comfortable and friendly environment (and thus a place to do research), (3) promote different ways of learning (e.g., visual, hearing, tactile) to increase students' attention span, and (4) make the librarian's job interesting, gratifying, and self-motivating.

All librarians viewed the current value placed by the profession on teaching IL skills as essential, especially with widespread student use of the Internet and subsequent information overload as common factors they had observed. Some librarians mentioned the need to have a required class to keep students actively involved; others suggested that these skills should be taught at the high school level. One librarian mentioned the need

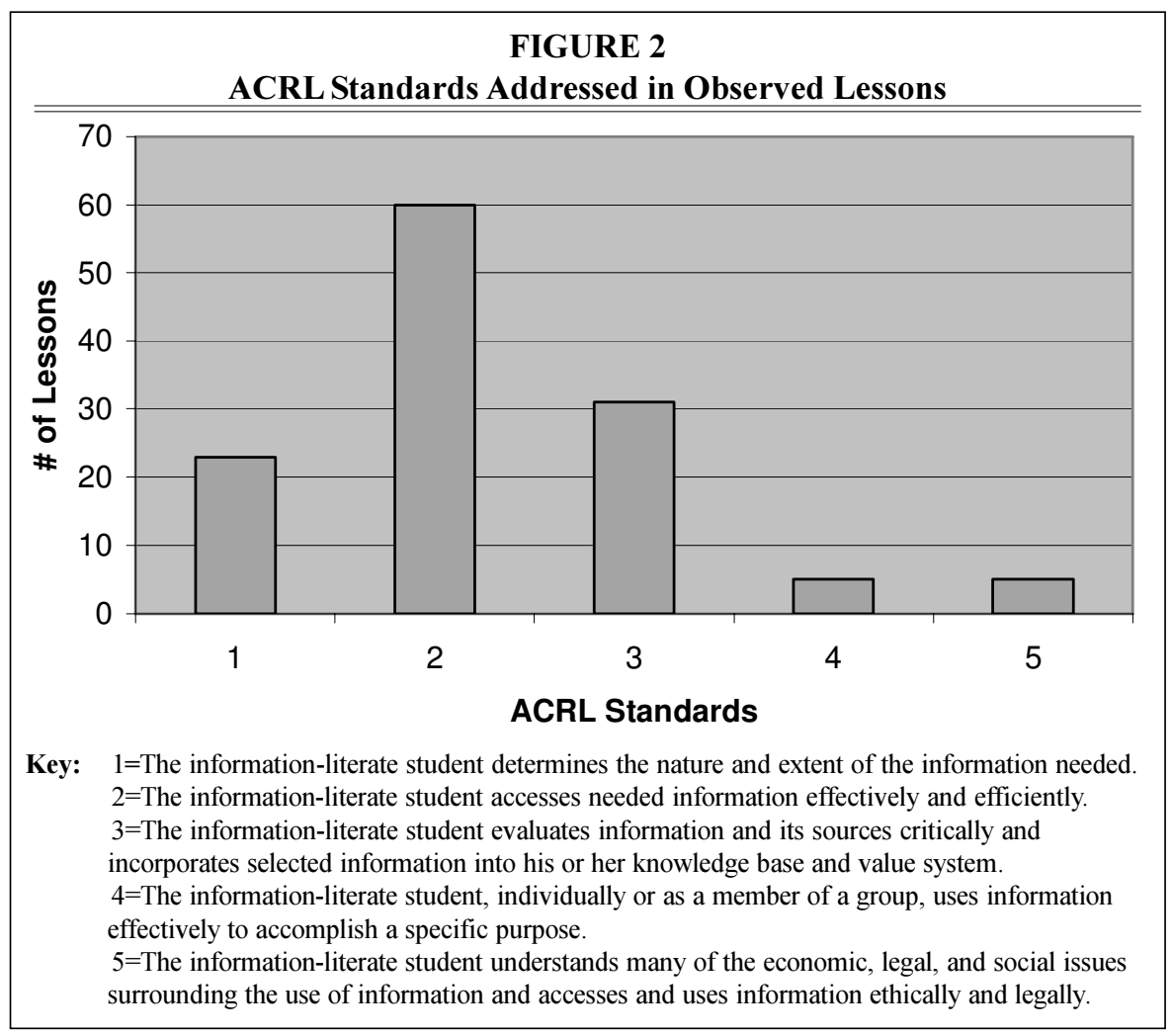




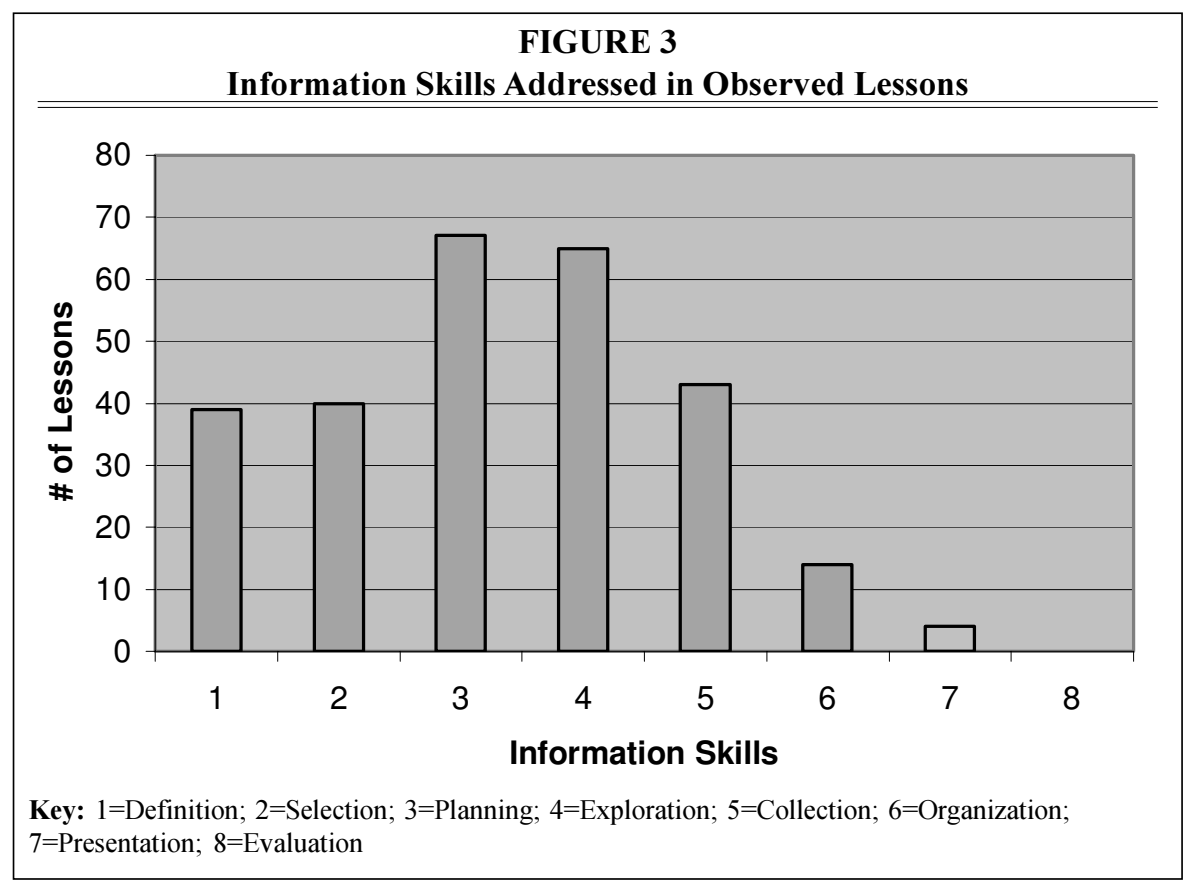

to get students working on their own to acquire such skills.

When asked what they liked best about teaching, the librarians most often cited "students," especially students who are motivated and active in the classroom. The second best thing mentioned about teaching was sharing knowledge and helping students. Some librarians mentioned the satisfaction they experienced when they linked their instruction to students' needs and felt they were learning right along with the students. The aspects of teaching librarians least liked were apathetic students, time constraints, lack of resources, and the politics of higher education.

Research question \#2. At the community college level, which of the ACRL Information Literacy Standards and Motivation Overlay's research stages and information literacy skills receive the most/least emphasis during information literacy skills instruction?

A total of sixty-nine lesson observations were analyzed for this study. Each lesson was assessed in terms of which of the nine motivational goals from the Motivation Overlay for Information Skills Instruction were addressed.
Coders categorized each lesson in terms of the five ACRL IL standards. (See figure 2.) The most commonly addressed standard was the second standard (The information-literate student accesses needed information effectively and efficiently). Analysis also revealed that the fourth standard (The information-literate student, individually or as a member of a group, uses information effectively to accomplish a specific purpose) and the fifth standard (The information literate-student understands many of the economic, legal, and social issues) were seldom addressed.

The observed lessons were analyzed to determine which of the eight IL skills from the Motivation Overlay for Information Literacy Skills Instruction were addressed. (See figure 3.) Results indicate that most lessons focused mainly on planning and exploration skills, and only a few addressed presentation and evaluation skills. Grouping information skills by research stage indicates that 54 percent of the lessons focused on the "beginning" stage, 45 percent targeted the "during" stage (particularly the earlier phases), and 
only one percent addressed the "ending" stage of the research process. (See figure 4.)

Research question \#3. What motivational techniques are used by community college librarians (CCLs) in their information literacy skills instruction, and how do they differ from those used by school librarians?

A total of sixty-nine lesson observations were completed in this study as compared to eighty-four lesson observations in the earlier Small study. From the sixty-nine narratives, a total of 1,423 ARCS strategies were extracted. (See figure 5.)

A comparison of the results of this study with the Small study revealed consistent patterns across ARCS components. (See table 1.) Attention strategies comprised more than one half $(754$, or $53 \%)$ of all strategies used by both groups. The amount of relevance (341, or $24 \%$ ) and confidence $(278$, or $20 \%$ ) strategies was approximately even. The fewest strategies used were satisfaction strategies (50, or $4 \%$ ). In addition, it was found that CCLs used proportionately fewer overall motivational strategies and incorporated more relevance and confidence strategies and fewer attention and satisfaction strategies per site than the K-8 LMSs. However, the general number of strategies (most for

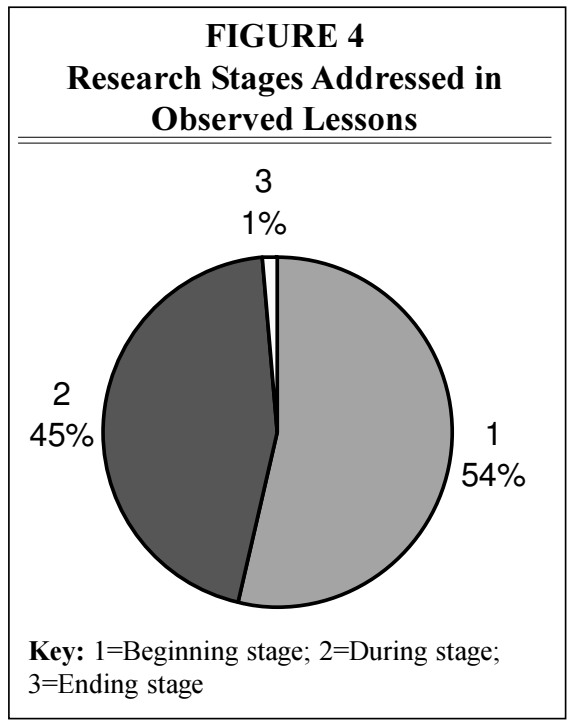

attention, least for satisfaction, relevance and confidence about the same) was the same for both settings.

An analysis by site found the total number of motivational strategies used ranged from 99 to 292. (See table 2.) The mean number of strategies ranged from 9.9 at site 7 to 29.2 at site 4 . The average overall number of strategies per lesson was 22.2. Librarians at sites 5 and 7 incorporated the fewest number of motiva-

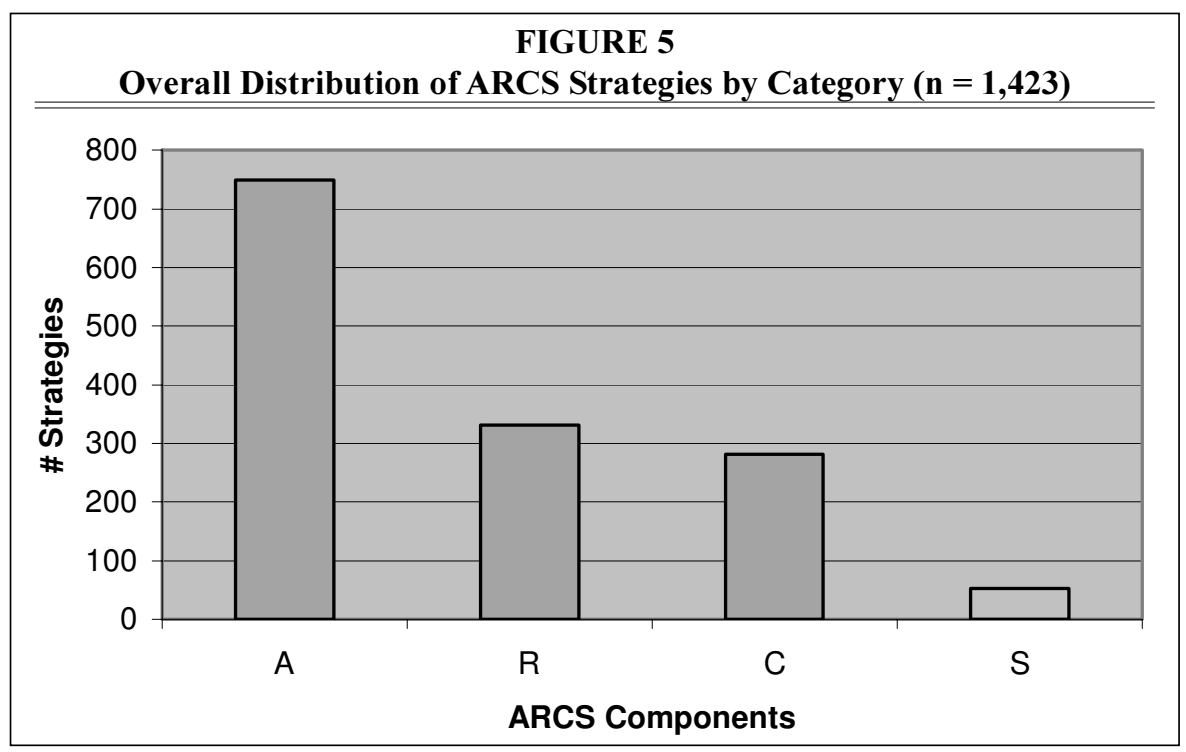


TABLE 1

Comparison of CCL and LMS Use of Motivational Strategies

\begin{tabular}{lrrrrrr}
\hline \hline ARCS Strategy Type & \multicolumn{1}{c}{ CCL } & Mean $(\mathbf{n}=\mathbf{7})$ & \multicolumn{2}{c}{ LMS } & Mean $(\mathbf{n}=\mathbf{8})$ \\
\hline Attention & 754 & $(53 \%)$ & 108 & 1,136 & $(56 \%)$ & 142 \\
Relevance & 341 & $(24 \%)$ & 49 & 331 & $(16 \%)$ & 41 \\
Confidence & 278 & $(20 \%)$ & 40 & 299 & $(15 \%)$ & 37 \\
Satisfaction & 50 & $(4 \%)$ & 7 & 260 & $(13 \%)$ & 33 \\
\hline Total & $\mathbf{1 , 4 2 3}$ & $(\mathbf{1 0 1 \% ) *}$ & $\mathbf{2 0 4}$ & $\mathbf{2 , 0 2 6}(\mathbf{1 0 0 \% )}$ & $\mathbf{2 5 3}$ \\
* Does not equal & $100 \%$ due to rounding error
\end{tabular}

tional strategies into their lessons; the librarian at site 4 incorporated the most.

A further breakdown of ARCS strategies by site indicates that the percentage of strategies used was relatively consistent across sites, with the most strategies being attention strategies, the least number of strategies being satisfaction strategies, and relevance and confidence strategies about even. (See table 3.) This is consistent with the Small study.

A closer look at the subcomponents of the attention strategy in table 4 reveals that slightly less than half of the strategies used were categorized as perceptual arousal (e.g., novelty, humor, enthusiasm, emphasizing important information). The remainder of the attention strategies were split almost evenly between inquiry arousal (e.g., problem solving, questioning) and variability (e.g., variety of media, student grouping, teaching methods). The emphasis on perceptual arousal strategies is consistent with what CCLs described as their teaching philosophy and favorite methods in the preand postobservation interviews.

In contrast, in the 1999 Small study, inquiry arousal strategies (mostly questioning) accounted for 51 percent of the attention strategy. ${ }^{54}$ Variability was about the same for both studies.

Table 5 indicates the breakdown by ARCS subcomponent for each of the seven community college sites. It appears that the only subcomponents addressed to any high degree consistently across sites are relevance-goal orientation (R-GO) (e.g., role models, link to future goal) and confidence-success opportunities (C-SO) (e.g., practice opportunities, summaries). It should be noted that analysis revealed very few relevance-motive matching ( $R$ $\mathrm{MM}$ ) (e.g., matching examples to student interests) and confidence-learning requirements (C-LR) (e.g., specifying learning expectations). Few or no confidencepersonal control (C-PC) (e.g., joint setting of learning goals), satisfaction-natural consequences (S-NC) (e.g., opportunities to apply newly learned knowledge), and satisfaction-equity (S-E) (e.g., consistency of learning goals and lesson content) were addressed by CCLs. The most frequently addressed subcomponents were attention-perceptual arousal (A-PA) cited 348 times, confidence-success opportunities (C-SO) cited 242 times, attention-inquiry arousal (A-IA) cited 220 times, and relevance-goal orientation (R-GO) cited 208 times.

The fifty satisfaction strategies were categorized into two types of motivators:

\section{TABLE 2}

Use of Motivation Strategies by Site

\begin{tabular}{lcc} 
Site & \# of Strategies & $\begin{array}{c}\text { Mean per } \\
\text { Lesson }\end{array}$ \\
\hline Site 1 & 167 & 16.5 \\
Site 2 & 230 & 25.6 \\
Site 3 & 259 & 25.9 \\
Site 4 & 292 & 29.2 \\
Site 5 & 115 & 11.5 \\
Site 6 & 261 & 26.1 \\
Site 7 & 99 & 9.9 \\
\hline Total & $\mathbf{1 , 4 2 3}$ & $\mathbf{2 2 . 2}$ \\
\hline
\end{tabular}




\section{TABLE 3}

\section{Overall Distribution of ARCS for Each Site}

\section{Site/}

$\begin{array}{lllllllll}\text { Strategy } & \text { Site } 1 & \text { Site 2 } & \text { Site 3 } & \text { Site 4 } & \text { Site 5 } & \text { Site 6 } & \text { Site } 7 & \text { Total }\end{array}$

\begin{tabular}{lcccccccccr}
\hline $\mathbf{A}$ & $83(50 \%)$ & $130(57 \%)$ & $143(55 \%)$ & $160(54 \%)$ & $56(49 \%)$ & $139(53 \%)$ & $43(44 \%)$ & 754 \\
$\mathbf{R}$ & $36(22 \%)$ & $59(26 \%)$ & $53(21 \%)$ & $84(29 \%)$ & $26(23 \%)$ & 61 & $(24 \%)$ & 22 & $(22 \%)$ & 341 \\
$\mathbf{C}$ & $45(27 \%)$ & $29(12 \%)$ & 52 & $(20 \%)$ & $47(16 \%)$ & $24(21 \%)$ & $57(22 \%)$ & $24(25 \%)$ & 278 \\
S & $3(1 \%)$ & $12(5 \%)$ & $11(4 \%)$ & $1(0.3 \%)$ & $9(8 \%)$ & $4(1.5 \%)$ & $10(10 \%)$ & 50 \\
\hline Total & $\mathbf{1 6 7}$ & $\mathbf{2 3 0}$ & $\mathbf{2 5}$ & $\mathbf{2 9}$ & $\mathbf{1 1 5}$ & $\mathbf{2 6 1}$ & $\mathbf{9 9}$ & $\mathbf{1 , 4 2 3}$
\end{tabular}

intrinsic and extrinsic. An analysis of intrinsic motivators (those that tie learning success to effort and ability) and extrinsic motivators (rewards and punishments not connected directly to learning) was performed. An example of an intrinsic motivator from the data is, Most of you are savvy Internet users so you know when it turns to a hand that it's a link you can click on. An example of an extrinsic motivator is, I'll wait for you to look at me.

Results indicate that CCLs use more intrinsic motivators $(28$, or $56 \%$ ) than extrinsic motivators (22, or $44 \%)$. In contrast, the LMSs used only four $(2 \%)$ intrinsic motivators compared to 256 (98\%) extrinsic motivators with $\mathrm{K}-8$ students. (See table 6.) It is reasonable that more extrinsic motivators would be required when teaching young children than when teaching adults. It is interesting that almost one half of all motivators used by CCLs were extrinsic in nature.

An additional analysis of the twentytwo extrinsic motivators showed that 91 percent (20) were informational in nature (e.g., That's right. In the catalog, you use subject headings to broaden the number of hits) as compared to 9 percent (2) controlling (e.g., (to professor) We're having a problem paying attention, so it's good you're back; (to students) Maybe you'll pay more attention with your professor here). This result is almost identical to the earlier study. (See table 7.)

Research question \#4. What task engagement and information-seeking behaviors are exhibited by community college students as a result of specific motivational techniques used during information literacy skills instruction.

A total of 997 on- and off-task behaviors was recorded by the observers over the sixty-nine lessons. (See table 8.) Most of those $(653$, or $65 \%)$ were on-task behaviors, but more than a third (343, or 35\%) were off-task behaviors. Examples of recorded off-task behaviors include students playing games on a cell phone, reading a magazine, and talking among themselves.

During one lesson at site 5, students asked the librarian to speak louder because they could not hear her. She responded that she could not and that they should move closer. Most did not move and, probably because they could not hear

\begin{tabular}{|c|c|c|}
\hline \multicolumn{3}{|c|}{$\begin{array}{c}\text { TABLE } 4 \\
\text { Number of Overall Strategies for Each Attention } \\
\text { Subcomponent for CCL and LMS }\end{array}$} \\
\hline Subcomponents of Attention & \# Strategies by CCL & \# Strategies by LMS \\
\hline $\bar{A}$ - IA (Inquiry Arousal) & $220(29 \%)$ & $581(51 \%)$ \\
\hline A - PA (Perceptual Arousal) & $350(46 \%)$ & $287(25 \%)$ \\
\hline A $-\mathrm{V}$ (Variability) & $186(25 \%)$ & $268(24 \%)$ \\
\hline Total & 756 & 1,136 \\
\hline
\end{tabular}




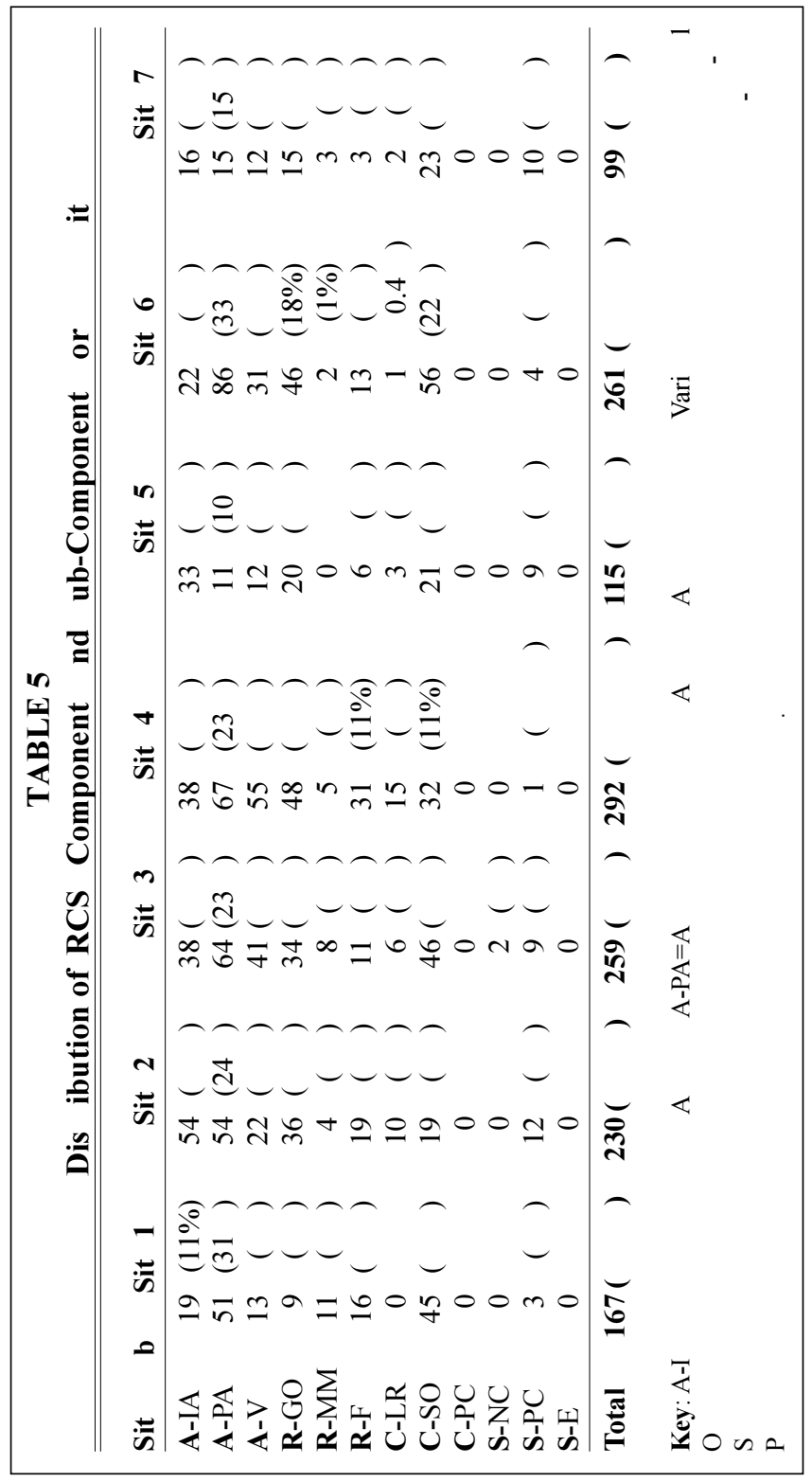

task behaviors in the Small study. In that study, overusing a particular motivation strategy, such as asking multiple questions in a row or giving too many of the same kinds of example, was a cause of students' off-task behaviors.

In general, the sites with the fewest offtasks behaviors seemed to be ones where the librarian(s) interacted frequently with the students during the session, where students had a hands-on assignment during the lesson, and where there were enough computers to accommodate all the students.

An analysis by site revealed that six of the seven sites had a higher proportion of on-task than off-task behaviors. One of those, site 4, was almost evenly split between on- and off-task behaviors. At site 4, the librarian was good at using examples and injecting humor from time to time. However, throughout all ten sessions, students appeared restless,

what she was saying, many decided to do other things rather than pay attention to the lesson.

Many of the off-task behaviors across all sites seemed to occur when the librarian performed repeated Web searches. The results were that students became bored and restless and, in some cases, literally fell asleep. This appears to correspond to one of the teacher behaviors that triggered off- bored, and inattentive. The librarian appeared to be trying to review too many resources, interacting more with the computer than with the students. The librarian also was observed to be teaching at a fast pace. At one point, the librarian had to tell the professor that the class was not paying attention and the professor warned the student that they would be graded for the class. 


\begin{tabular}{|c|c|c|}
\hline \multicolumn{3}{|c|}{$\begin{array}{c}\text { TABLE } 6 \\
\text { Components of Satisfaction Strategies } \\
\end{array}$} \\
\hline Satisfaction Strategies & Total CCL & Total LMS \\
\hline Intrinsic Motivators & $28(56 \%)$ & $4(2 \%)$ \\
\hline Extrinsic Motivators & $22(44 \%)$ & $256(98 \%)$ \\
\hline Total & $50 \quad(3.5 \%)$ & $260(13 \%)$ \\
\hline
\end{tabular}

task behaviors also were recorded during this one lesson, including applying lipstick, talking about "dates," tapping pencils on the desks, getting up and leaving the room before the lesson was finished, coming into class late, coughing, yawning, and stretching.

Site 1 was the only site that recorded a higher number of off-task behaviors (108, or $58 \%$ ) than on-task behaviors $(79$, or $42 \%$ ). Off-task behaviors ranged from restlessness to whispering and laughing to getting up and going to the water fountain. The observer's notes also described the following off-task behaviors that occurred when the librarian was either speaking or waiting for a slow connection:

A cell phone belonging to a student sitting at the back of the room starts to ring. The student gets up and leaves the room to answer the call.

A pager goes off. The student retrieves it from his pack and reads the message before putting it back.

A female student pulls a small mirror and lipstick from her bag and carefully applies the lipstick.

In one of the lessons at site 1, the professor let the students leave before the class was over. It was also observed that, during some of the classes at site 1, many students did not seem to be paying attention, even though their professor was present.

A further analysis of the observations of site 1 revealed that 23 percent (25) of the off-task behaviors occurred during one lesson (lesson \#7). A closer look at lesson \#7 revealed that although the librarian seemed to interact well with the students (e.g., used a few jokes along his lesson and asked questions), he ignored it when students talked loudly off-topic. The librarian also never reminded the students not to surf the Web during the class, which several did. A number of other off-

Research question \#5. How do students perceive the motivational quality of their information literacy skills instruction?

One student was randomly selected following each observed lesson to respond to a brief interview protocol. (See appendix.) The interviews were designed to collect students' impressions of the instruction just received. A total of sixtynine interviews were conducted.

Students first were asked to rate the lesson in which they had just participated on a Likert-type scale from "very interesting" to "very boring." A majority of students $(44$, or $64 \%)$ rated their lesson either "somewhat interesting" or "very interesting," and only about 10 percent (7) rated it "somewhat or very boring." Eighteen students $(26 \%)$ said the lesson was "sometimes interesting, sometimes boring."

When asked how confident they felt about their ability to apply what they learned, 65 percent (45) of students felt "very confident," compared to 32 percent who felt "somewhat confident." Only two students $(3 \%)$ were "not very confident" or "not at all confident." It should be mentioned that some of the students who felt very confident indicated that they had been already exposed to the material covered and thus felt "very bored" with the lesson.

\begin{tabular}{|lcc|}
\hline \multicolumn{3}{|c|}{ TABLE 7 } \\
Extrinsic Motivators \\
\hline \hline Extrinsic & $\begin{array}{c}\text { Total } \\
\text { For CCL }\end{array}$ & $\begin{array}{c}\text { Total } \\
\text { For LMS }\end{array}$ \\
\hline Controlling & $2(9 \%)$ & $26(10 \%)$ \\
Informational & $20(91 \%)$ & $230(90 \%)$ \\
\hline Total & $22(44 \%)$ & $256(99 \%)$ \\
\hline
\end{tabular}


Students were asked to cite the most important knowledge or skill they had gained from the instruction just received. Responses were categorized by broad information skill. (See table 9.)

More than half the skills cited as most important by students were exploration skills (e.g., finding information within sources, keyword searching, how to search different online resources) (50, or $53 \%$ ), followed by selection skills (16, or $17 \%)$.

Students were asked about

\begin{tabular}{|lccc|}
\hline \multicolumn{4}{|c|}{ TABLE 8 } \\
Distribution of On- and Off-task \\
Behaviors for Each Site
\end{tabular}
ways they planned to use what they had just learned. Sixty students (87\%) said they would use their new knowledge or skills for academic purposes for completing current assignments and/or for future research in other classes. Nine students $(13 \%)$ mentioned that the skills just learned would be used for personal use (e.g., helping others finding material, for fun, and job searching).

Research question \#6. What is the level and extent of community college faculty participation in information literacy skills instruction, and how does participation/ nonparticipation affect student motivation?

When asked about collaboration with faculty to teach IL skills, seven out of ten librarians $(70 \%)$ indicated that they collaborated; three did not because of lack of interest from the faculty and time constraints. Those who collaborated stated that they tailored the instruction according to the faculty's needs. Most described their instruction as "bibliographic instruction."

The participating librarians emphasized the important role that their library administration and reference staff play in providing support to deliver instruction. This was evidenced through facilities and time provision. The heads of departments and some faculty also were mentioned as important sources of support.

An analysis of the observation data revealed that all seven sites had examples of teacher presence during the lessons observed. The smallest number of faculty

participations was observed at sites 5 and 7. Interestingly, these two sites also had the lowest number of motivational instructional strategies used by librarians.

Only site 1 reported faculty presence in all ten lessons; however, site 1 also was the site with the highest rate of off-task behaviors (58\%). An analysis of faculty activities during site 1 lessons revealed a wide range of behaviors. (See figure 6.) A range of behaviors was observed, from helping individual students to constantly asking questions to interrupting the librarian to helping distribute handouts.

Some of these behaviors (e.g., a disapproving look, interrupting, classifying a subgroup as the "good group, using "leaving class early" as a reward) might be considered negative reinforcements. These types of behaviors probably contributed to at least some of the disruptive, off-task behaviors exhibited by students and the loss of class control by the librarian during the observed lessons at this site.

Research question \#7. In what ways do community college librarians use technology in information literacy instruction, and does the use of technology subsequently affect student motivation?

Technology plays a major role in IL skills instruction at the community college level. Of the sixty-nine lessons observed, only one did not incorporate technology at all. A variety of technologies were included in the lessons as either tools to deliver content or the focus of the lesson, 


\section{TABLE 9}

Most Important Knowledge/Skills Learned Cited by Students

\begin{tabular}{|c|c|c|}
\hline Skills & Frequency & $\%$ \\
\hline \multicolumn{3}{|l|}{ Definition } \\
\hline - Steps in the overall research process & 6 & 6 \\
\hline \multicolumn{3}{|l|}{ Selection } \\
\hline - Awareness of library resources & 14 & \\
\hline - Determine the range of possible sources & 2 & 17 \\
\hline Planning & 0 & 0 \\
\hline \multicolumn{3}{|l|}{ Exploration } \\
\hline - Locate sources (intellectually and physically) & 13 & \\
\hline - Find information within diverse sources & 6 & \\
\hline - Remote access & 3 & \\
\hline - Keyword searching skills & 18 & \\
\hline - How to search different resources & 10 & 53 \\
\hline \multicolumn{3}{|l|}{ Collection } \\
\hline - Extract information from sources & 2 & \\
\hline - Evaluate information and/or sources & 7 & 10 \\
\hline Organization & 0 & 0 \\
\hline \multicolumn{3}{|l|}{ Presentation } \\
\hline - Citation guidelines & 4 & 4 \\
\hline Evaluation & 0 & 0 \\
\hline Other (e.g., how to operate a computer) & 9 & 10 \\
\hline
\end{tabular}

such as lessons about the online library catalog, online databases, electronic journals, and Internet search engines.

Three of the sites were observed to use PowerPoint to present their lessons. In fact, the librarian at site 4 used PowerPoint as a presentation tool for all ten lessons. It also should be noted that the librarian at site 4 had the highest number of motivational strategies incorporated into instruction. Site 7 was the only site at which the librarian used Microsoft Word as an instructional technology.

A wide range of databases was taught. Those databases most frequently documented in the observations were EBSCO, ProQuest, Expanded Academic ASAP, Infotrac, CQ Researcher, SIRS, and LexisNexus. The library catalog also was included in at least one lesson at every site. Google was the most frequently taught search engine.

Although librarians used a wide variety of technologies as the content focus of most lessons, the technologies were taught almost exclusively as resources, a reminder of lessons from years past that "taught" the dictionary or the encyclopedia to students rather than situating it as a tool for use in the larger information problem-solving process. Similarly, most observed lessons focused on location and access skills (e.g., demonstrating how to access various databases and Web sites and how to find information within them), while a few targeted ways to (1) define the assignment or learning task; (2) determine the best resources for completing that assignment or achieving that task; (3) extract, synthesize, and organize information for presentation; and/or (4) evaluate resources and their content.

\section{Discussion}

The purpose of this study was to identify the motivational strategies used by community college librarians in information skills instruction. Data analyses have revealed several interesting results that merit additional discussion.

1. It appears that, more than ever before, community college librarians are 


\section{FIGURE 6}

\section{Faculty Participation Behaviors in Site 1 Lessons}

\section{Lesson \#1}

- Teacher actively asking questions to the librarian during the lesson.

- Teacher helped students one-on-one.

- Teacher gave a disapproving look to two students who were laughing during the lesson.

\section{Lesson \#2}

- Teacher walked around the class during the lesson.

- Teacher constantly asked questions.

- Teacher discussed with students one-on-one during the class. Their discussion was quite loud when the librarian was not talking.

\section{Lesson \#3}

- Teacher constantly asked questions during the lesson.

\section{Lesson \#4:}

- Teacher interrupted the librarian and asked the librarian to focus to specific examples.

- Teacher asked questions during class.

- Teacher gave some instructions to her students in the middle of the instructions.

- Teacher saw a student needed help and immediately called the librarian.

\section{Lesson \#5}

- Teacher asked opinion from the librarian.

- Teacher gave compliment to the librarian.

- Teacher actively helped the students.

- Teacher gave encouraging words to the students.

\section{Lesson \#6}

- Teacher interrupted the class and pointed to a related reading for the class.

- Teacher helped student one on one.

- Teacher helped to control the chaotic class.

\section{Lesson \#7}

- Teacher told the librarian to give sophisticated stuff to the students whom she referred as a "good group."

- Teacher helped to pass around handouts.

- Teacher helped student one-on-one.

\section{Lesson \#8}

- Teacher asked the librarian to talk about a specific topic.

- Teacher let the students leave early if they'd found everything for their papers.

\section{Lesson \#9}

- At the beginning of the class, the teacher apologized to the students because they need to share the computer. The teacher also said if they are done early, they can leave the class (so other students can use the computer to search for their research topic).

\section{Lesson \#10}

- Teacher helped students one-on-one.

- $\quad$ The teacher told the students that they can leave when they are done. 
more likely to have some type of formal teacher training in their background. They also have fewer years of on-the-job experience than their school library counterparts. They value their role as instructors and appreciate motivated students. They also find themselves with fewer resources and less support than they need. When asked to provide a wish list for support of instructional programs, the librarians in this study mentioned the following:

- having an additional staff member;

- collaborating with all librarians;

- improving facilities by watching the number of computers in lab;

- having additional training;

- having additional time by being freed from other duties;

- being recognized for their roles, especially by the faculty; vices;

- improving computer support ser-

- recognizing ILskills as "Library 101."

2. Use of the library for instructional purposes appears to be greater at specific times of the year. These times seem to coincide with the "beginning" stage of the research process, when faculty bring their students to the library for orientation to the library and its resources and to learn to use the databases. This results in emphasis on early-stage research skills, focusing on location and access skills with little or no time devoted to follow-up with late "during-" and "ending"-stage skills, such as organization, presentation, and evaluation skills. This finding is further reinforced by the large number of attention (both perceptual arousal and inquiry arousal) strategies used by librarians in their instruction and the almost nonexistent use of satisfaction strategies.

3. All librarians used a variety of motivational strategies in their instruction. However, the range of use among the librarians was almost 3 to 1 , with the librarian at site 7 using an average of 9.9 strategies per lesson and the librarian at site 4 using an average of 29.2 strategies per lesson. The number of strategies did not appear to be a factor in the motivation of students because site 7 had the highest per- centage of on-task behaviors of all the sites (and the lowest amount of faculty participation) and site 4 had almost as many offtask as on-task behaviors (it was also the site where PowerPoint was used for every class session). Site 7 also appears to have had a slightly more balanced approach to incorporating all of the ARCS components into the instruction.

4. A closer look at the use of ARCS subcomponents across sites found a serious lack of relevance-motive matching, relevance-familiarity, confidence-personal control, satisfaction-natural consequences strategies, satisfaction-positive consequences, and satisfaction-equity strategies used. Community college librarians need to be aware of the importance of incorporating strategies across all ARCS components into their instruction.

5. The overwhelming use of technology in sixty-eight of sixty-nine lessons indicates the vital role technology plays in teaching and learning in higher education. However, the repetitious nature of the majority of lessons (focusing on database searching) is potentially a source of boredom for students. Although students appear to value learning search strategies and using technology, the overemphasis on searching, without situating the search within a relevant problem-solving context and providing students with enough practice with feedback, may result in lowered student motivation.

A comparison of the results of this study with the Small study of K-8 librarians indicates a number of differences, some predictable and some surprising. Most CCL lessons focused on technology, specifically databases, whereas most LMS lessons were broader in scope, teaching students basic information problem-solving skills for a variety of applications. This is reasonable because younger children need to be taught a foundation of research skills with broad application.

The difference in number of years of service also was somewhat expected. The number of school LMSs nearing or at retirement is a major concern for the profession. CCLs who are newer to service 
are more likely to have a better technology and teaching background. The heavy emphasis on database and other information technologies in almost all CCL lessons is evidence of this, as well as the need for more complex and sophisticated information-seeking skills among older students. This also may account for the majority of perceptual arousal strategies, using technology to gain and maintain community college students' attention.

CCLs used fewer strategies per site than LMSs did. This may be due to a perceived need for more motivational strategies to maintain young children's attention and interest. This is consistent with the fact that LMSs used mostly inquiry arousal strategies and more extrinsic strategies to keep young students involved and active.

Finally, both groups experienced offtask student behaviors as the result of an overuse/repetition of certain strategies, which may have caused learning boredom (for the LMS, too many questions; for the CCL, too many database searches). Related to this, off-task behaviors by community college students also may have been the result of too little instructor-student and student-student interactivity.

\section{Future Research}

The results of this study have yielded rich, descriptive data that offer an initial "glimpse" into a relatively unexplored area of research - the motivational aspects of library and information skills instruction. This research provides academic librarians (particularly those working in community college libraries), who are challenged to find exciting ways to present IL instruction to students, with insights into a range of effective teaching methods that increase student motivation and awareness of methods that seem to decrease student motivation.

This exploratory study offers a glimpse into the community college library instructional setting. The findings provide a foundation for designing future research studies to test specific motivational interventions that compare changes in student attitudes and learning outcomes. For ex- ample, although it appears that some strategies (such as more frequent interaction between librarian and students and more hands-on practice) will result in higher student motivation and that reviewing too many resources, interacting more with the computer than with the students, teaching at a fast pace, and using negative reinforcement (e.g., warning students that their behavior will affect their grade) appear to negatively affect student motivation, it is not clear under what circumstances and with which students these strategies seem to have more impact

The results of this research "snapshot" identify a number of areas in need of further exploration and investigation. For example, although clearly two-thirds of students interviewed described their lessons as motivating, future research needs to look more closely at student attitudes and behaviors to determine specific strategies that students find motivating and de-motivating.

In addition, it is important to collect data that reveal whether students will have the broad range of basic IL skills that are needed to be successful in their assignments and projects when they reach college level. If students lack some or all of these skills, it is necessary to focus on the entire research process rather than on exploration and collection skills.

Furthermore, we need to look behind the scenes at faculty participation. For example, what interactions lead up to and follow the lesson delivery? Perhaps a survey of faculty whose students participated in this study would have revealed some interesting perceptions of the collaborative process and the importance of IL skills instruction.

It also would be interesting to determine what happens to students after the instruction is over. Is there follow-up in the classroom? How successful are students' completed research assignments and projects? What skills and knowledge do they still lack?

Future research on the motivational aspects of IL skills instruction may include the following: a large-scale replication of this study; follow-up exploration of cer- 
tain findings; replication of this study in high school and in four-year college and university library settings; and experiments in which community college librarians are trained to incorporate and deliver specific motivational strategies into their IL skills instruction. The effective use of motivational strategies in IL skills instruction helps to develop students' curiosity, intrinsic motivation, information-seeking behaviors, and a lifelong love of learning. It is hoped that this initial research study will stimulate future research in this area by both researchers and practitioners.

\section{Notes}

1. American Library Association, American Library Association Presidential Committee on Information Literacy: Final Report. ERIC Clearinghouse on Information Technology ED315074 (Chicago: ALA, 1989), 1.

2. Loanne Snavely and Natasha A. Cooper, "The Information Literacy Debate," Journal of Academic Librarianship 23 (Jan. 1997): 9-14.

3. Michele Mednick, Information Literacy: The New Challenge, ERIC Clearinghouse on Information Technology ED464692. 2002.

4. Abby Kasowitz-Scheer and Michael Pasqualoni, "Information Literacy Instruction in Higher Education: Trends and Issues," ERIC Digest (June 2002): 1.

5. Mednick, Information Literacy.

6. Academic Senate for California Community Colleges, Sacramento, Library Faculty in California Community College Libraries: Qualifications, Roles, E Responsibilities, ERIC Clearinghouse on Information Technology ED395630, 1996.

7. Charles Hayes, Curriculum Design/Instruction in Library Research Skills, ERIC Clearinghouse on Information Technology ED456851, 2001.

8. Maureen Kilcullen, "Teaching Librarians to Teach: Recommendations on What We Need to Know," Reference Services Review (summer 1998): 7-18.

9. Carla J. Stoffle, "Literacy 101 for the Digital Age," American Libraries 29 (Dec. 1998): 48.

10. Mednick, Information Literacy.

11. Ruth V. Small, et al., "Motivational Aspects of Library and Information Skills Instruction: The Role of the Library Media Specialist," in Instructional Interventions for Information Use, ed. D.Callison, J. McGreggor, and R. Small (San Jose, Calif.: Hi Willow Research and Publishing, 1998).

12. Patricia Senn Breivik, Student Learning in the Information Age (Phoenix, Ariz.: Oryx, 1998).

13. Kasowitz-Scheer and Pasqualoni, "Information Literacy Instruction in Higher Education."

14. ALA, American Library Association Presidential Committee on Information Literacy.

15. Profeta and Kendrick, 2002; Hayes, Curriculum Design/Instruction in Library Research Skills.

16. Academic Senate for California Community Colleges, Library Faculty in California Community College Libraries, 2.

17. Ibid., 3.

18. Association of College \& Research Libraries, Information Literacy Competency Standards for Higher Education: Standards, Performance Indicators and Outcomes, January 18, 2000. Available online from http:/ / www.ala.org/acrl/ilstandardlo.html.

19. Burdick, T.A. (1996, Fall). "Success and diversity in information seeking: Gender and the information search styles model." School Library Media Quarterly, 19-26.

20. Kilcullen, "Teaching Libraries to Teach," 9.

21. Association of College and Research Libraries, "Competency Standards for Higher Education," Teacher-Librarian 28, no. 3 (Feb. 2001): 16-22.

22. Ruth V. Small, B. M. Dodge, and X. Jiang, "Dimensions of Interest and Boredom in Instructional Situations," in Proceedings of Annual Conference of Association for Educational Communications and Technology, Indianapolis, Indiana, 1996.

23. For example, Newby, T.J. (1991). "Classroom motivation: Strategies of first-year teachers." Journal of Educational Psychology, 83(2), 195-200; and Small, "An Exploratory Study of Motivational Strategies in Library and Information Skills Instruction," January 1999. Available online from School Library Media Research at http:/ / www.ala.org/aasl/SLMR/index.html.

24. Carol C. Kuhlthau, "Information Search Process: A Summary of Research and Implications for School Library Media Programs," School Library Media Quarterly 18 (fall 1989): 19-25; , "Implementing a Process Approach to Information Skills: A Study Identifying Indicators of Success in Library Media Programs," School Library Media Quarterly 22 (fall 1993): 11-18.

25. __ "Implementing a Process Approach to Information Skills," 13.

26. John M. Keller, "The Systematic Process of Motivational Design," Performance and Instruction 26 (Nov./Dec. 1987): 1-8; Jere Brophy, "Synthesis of Research on Strategies for Motivating 
Students to Learn," Educational Leadership 45 (Oct. 1987): 40-48.

27. Small, Dodge, and Jiang, "Dimensions of Interest and Boredom in Instructional Situations."

28. Small, "An Exploratory Study of Motivational Strategies in Library and Information Skills Instruction."

29. Keller, J.M. (1983). “Motivational design of instruction." In C.M. Reigeluth (ed.), Instructional Design Theories and Models: An Overview of Their Current Status. Hillsdale, NJ: Erlbaum, 383-434.

30. For example, Newby, 1991.

31. Ruth V. Small and Marilyn P. Arnone, Turning Kids On to Research: The Power of Motivation (Englewood, Colo.: Libraries Unlimited, Inc., 2000); Small, R.V. (1997, Dec.). “Designing motivation into library and information skills instruction." School Library Media Research (formerly School Library Media Quarterly-Electronic)(first issue, lead article). Available online at http:www.ala.org/ aasl/SLMQ/slmq_toc.html.

32. For example, Rotter, J.B., 1996. “Generalized expectancies for internal versus external control of reinforcement." Psychological Monographs 80:000-00.; deCharms, R., 1968. Personal Causation. San Diego: Academic Press; Deci, E.L. (1975). Intrinsic Motivation. New York, Plenum.

33. For example, Brophy, "Synthesis of Research on Strategies for Motivating Students to Learn"; Butler, R. 1988. "Enhancing and undermining intrinsic motivation: The effects of taskinvolving and ego-involving evaluation on interest and performance." British Journal of Education Psychology 58:1-14; Lepper, M.R. (1988). "Motivational considerations in the study of instruction." Cognition and Instruction. 5, 289-309; Gottfried, A.E. 1985. "Academic intrinsic motivation in elementary and junior high school students." Journal of Education Psychology 37:631-45.

34. Deci, 1975; Deci, E.L. \& Ryan, R.M. (1985). Intrinsic Motivation and Self-Determination in Human Behavior. New York: Plenum.

35. Marshall, H.H. (1987). "Motivational strategies of three fifth-grade teachers." The Elementary School Journal, 88(2), 135-150.

36. Deci and Ryan, 1985.

37. Lepper, M.R., Greene, D., and Nisbett, E.R. (1973). “Undermining children's intrinsic interest with extrinsic reward: a test of the overjustification of hypothesis. Journal of Personality and Social Psychology, 28, 129-137; Lepper, 1988.

38. For example, Small, "An Exploratory Study of Motivational Strategies in Library and Information Skills Instruction"; Keller, 1983; Kuhlthau, "Implementing a Process Approach to Information Skills."

39. Small and Arnone, Turning Kids On to Research.

40. Karen Muronaga and Violet Harada, "The Art of Collaboration," Teacher-Librarian 27, no. 1 (Oct. 1999): 9-14.

41. Neal Baker and Steve McKinzie, "Librarians and Faculty in Tandem: Taking Our Cue from the Evening News," Reference and User Services Quarterly 37 (fall 1997): 19.

42. Christine Susan Bruce, The Seven Faces of Information Literacy (Adelaide, Australia: Auslib Press, 1997).

43. Stoffle, "Literacy 101 for the Digital Age."

44. P. Sallman, "Rx for Success: Technology as a Motivational Tool to Enhance Learning," Media Horizons: Journal of the Missouri Association of School Librarians 13 (spring 1997): 20.

45. D. M. Smith, "Embracing Information Literacy in a Learning Community" (unpublished manuscript).

46. Academic Senate for California Community Colleges, Sacramento, Information Competency in the California Community Colleges, ERIC Clearinghouse on Information Technology ED421191, 1998; Katherine A. Branch and Debra L. Gilchrist, “Library Instruction and Information Literacy in Community and Technical Colleges," RQ 35 (summer 1996): 476-83.

47. Smith, "Embracing Information Literacy in a Learning Community."

48. Ebo Otuya and Alice Mitchell, Today's College Students: Varied Characteristics by Sector, ERIC Clearinghouse on Information Technology ED382087, 1994.

49. Carla Higgins and Mary Jane Cedar Face, "Integrating Information Literacy Skills," Reference Services Review 26 (fall/winter 1998): 17-31; Branch and Gilchrist, "Library Instruction and Information Literacy in Community and Technical Colleges."

50. Branch and Gilchrist, "Library Instruction and Information Literacy in Community and Technical Colleges."

51. Kilcullen, "Teaching Librarians to Teach," 7.

52. Ibid., 7-18.

53. Small, Dodge, and Jiang, "Dimensions of Interest and Boredom in Instructional Situations."

54. Small, "An Exploratory Study of Motivational Strategies in Library and Information Skills Instruction." 


\section{APPENDIX}

\section{Data Collection Forms}

\section{Librarian Interview Preobservation Protocol}

What is the approximate enrollment at your college?

What best describes the geographic location of your college?

$\square$ urban $\square$ suburban $\square$ rural

Describe the type and range of students who attend your college.

Describe your library's total instructional program for students.

How many years have you been an academic librarian?

How many years have you been an academic librarian at this college?

Approximately how many classes (on average) come to the library for information literacy instruction per week?

Of those, how many do you (personally) teach?

What is the topic or topics you most frequently teach?

What are your feelings about the increasing emphasis on teaching information and technology literacy skills instruction at the college level?

What do you like best about teaching?

What do you like least about teaching?

What technology(ies) do you most often teach students to use?

What technology(ies) do you most often use to teach students?

Thank you. 


\section{Observation Form}

Observer's Name:

Site \#:

Date:

Lesson Starting Time Ending Time

Lesson Title:

Information Skill(s):

\# of students

Level of students: $\square 1^{\text {st }}$ year $\square 2^{\text {nd }}$ year $\square$ other (please specify)

Place of lesson $\square$ library $\square$ classroom $\square$ other (please specify)

Description of teaching setting:

Librarian Behaviors

Student Behaviors

\section{Student Interview Protocol}

1. What was the most important thing you learned in the instruction you just received?

2. How would you describe this lesson?

$\square$ very interesting

$\square$ somewhat interesting

$\square$ sometimes interesting, sometimes boring

$\square$ somewhat boring

$\square$ very boring

3. In what way(s) will you use what you have learned from this lesson?

4. How confident do you feel that you can apply what you have learned from this lesson? $\square$ very confident

$\square$ somewhat confident

$\square$ not very confident

$\square$ not at all confident 


\section{Librarian Postobservation Interview Protocol}

What is your general teaching philosophy?

Where, how, from whom did you learn to teach?

What are some of your favorite/most frequently used teaching techniques?

Why do you prefer these techniques?

Do you ever collaborate with faculty to teach information skills lessons?

If yes, describe one instance. If no, why not?

What support do you receive to deliver this instruction and from whom?

What additional support do you wish you had in your efforts to deliver information literacy instruction and from whom?

Do you have any additional comments or questions about any topic covered or about this research study?

Thank you. 